\title{
correspondence
}

\section{Lithium supplies}

SiR,-We fully support the contention of Walton and Spooner (June 17, pages $533-5$ ) that there is a pressing need to identify further resources of lithium, but would take issue with them on a few points.

In Table 2 some $50 \%$ of their total resources derives from North American brine deposits. However, J. D. Vine (Journ. Research U.S. Geol. Surv., 3, $4,479-85$; 1975) recently emphasised that the amount of recoverable lithium at Silver Peak is, in fact, lower than the published reserves by a factor of 10 . Should a similar factor apply to other brine deposits the shortfall between Western world reserves and projected consumption becomes critically magnified.

Our present, limited, understanding of the geochemistry of lithium suggests that more small brine and pegmatite sources may be discovered in the developed countries. Even so, the best prospects for large reserves lie in Africa and South America, sources which for various reasons may not automatically be available to the technologically advanced Western nations. We may be obliged to rely, therefore, on known smaller domestic deposits and on exploration and development of new types of lithium deposit.

Walton and Spooner state that the European countries "possess no presently identified significant lithium resources": though true of reserves it is not so of resources. Small lithium pegmatites and lithia brine flows are known in several European countries, including Great Britain, but none is exploited at present. Given suitable financial inducement to development, they could make a valuable though comparatively small contribution to our requirements.

Of more significance are the lithiumrich portions of the Variscan granites, in which lithium occurs largely in "lithionite" mica. In Cornwall, for example, parts of just such a major lithium resource have been affected by kaolinisation and some of the lithionite could be extracted during the working of china clay. As yet the distribution of lithionite-granite in the Cornubian batholith is imperfectly known and we have only sparse information on the variations in lithium content and none on isotopic composition. Nevertheless, exploitation of zinnwaldite mica from granites of the Czechoslovakian Erzge- birge, albeit under a different economic philosophy, indicates that this type of deposit may have an important role to play in the supply of future lithium requirements and argues for a direct programme of geological and chemical engineering research ino the lithium potentialities in the Western European Variscides.

\section{Yours faithfully,}

\section{K. E. BeER}

Institute of Geological Sciences,

Hoopern House,

Exeter

Exhibition Road,

\section{J. R. HAWKES}

London, $U K$

\section{Bran and sawdust}

SIR,--It was suggested by Dr Jukes (May 13, page 92) that bran and sawdust constitute a safe diet. This is not so. There is evidence (Mackarness, Not All in the Mind (Pan; 1976)) that, on an evolutionary. time scale, cereal is a recent addition to our diet, one to which we have not yet become adapted, and a Stone Age pre-cereal diet was recommended.

As for sawdust, it is highly likely that timber is carcinogenic: wood workers have a high incidence of nasal adenocarcinoma (Acheson et al., Brit. J. industr. Med., 29, 21; 1972), while mice bedded on wood shavings show an increase in so-called "spontaneous" tumors (Sabine et al., J. Natl Cancer Inst., 50, 1237; 1973).

It is high time to accept the fact that nothing whatever is completely safe. Yours faithfully,

Valda M. Craddock

$M R C$ Toxicology Unit,

Carshalton, Surrey

\section{Canned crab}

SIR,--In 1959 Ecuador declared the unoccupied lands of the Galapagos Archipelago a national park; by 1968 a department of national parks and wildlife was created to administer the park. The national park service service started collecting an entrance fee in 1972 that, in part, is used to finance conservation programs in the islands. Although conservation efforts have grown, tourism has grown more spectacularly. For instance, since 1969 the number of tourist boats have more than doubled.

There is currently an effort to extend the national park to protect the marine life near the Galapagos shores. It will be difficult to regulate the fishing but this may become necessary. Packing boats started to visit the islands regularly in 1972, allowing fishermen to go farther and stay out longer. Many of the endemic species such as the Galapagos penguin are dependent on small fish which could become commercially valuable. The Galapagos penguin is subject to total nesting failures suggesting that competing pressure from humans could, over a period of time, reduce their population.

Dramatic decreases in species number or composition will probably be detected but subtle changes could go unremarked. In 1972 when no more than 80 tourists were visiting Pta. Espinosa, Fernandina weekly, a hermit crab with a discarded film can marched through my camp in July and August. Our camp site was a mile from the tourist landing and we had no similar film canisters. The hermit crab's aluminium home should have heated up rapidly in the hot equatorial sun, which may be why the crab stayed in the shade of the mangroves. Pesticides have been found in almost every remote corner of the world; the film canister may be next.

\section{Yours faithfully,}

DeE Boersma

Institute for Environmental Studies,

University of Washington.

Seattle, Washington

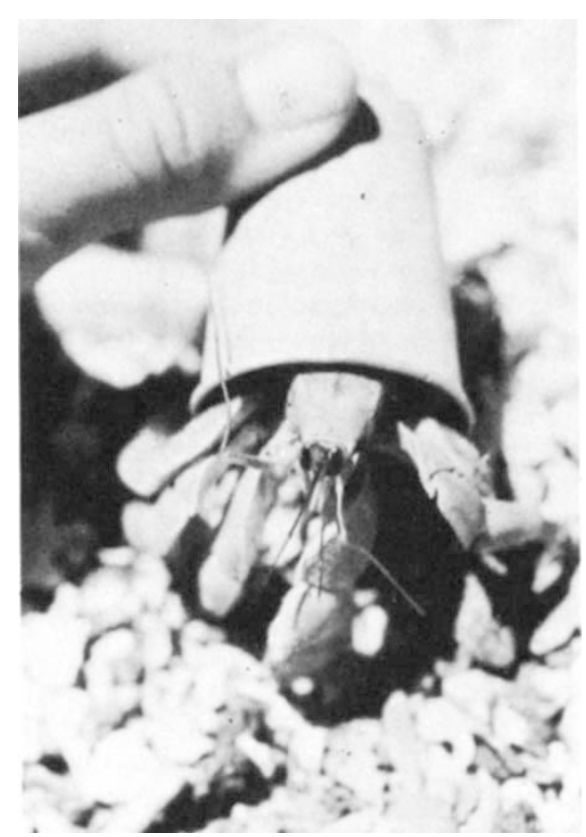

